\title{
The chemical composition of rumen bacteria and cell walls from rumen bacteria
}

\author{
BY N. J. HOOGENRAAD AND F. J. R. HIRD \\ Russell Grimwade School of Biochemistry, University of Melbourne, \\ Parkville, Victoria, Australia \\ (Received 5 May 1969-Accepted 7 fuly 1969)
}

\begin{abstract}
I. Rumen bacteria were prepared in bulk from freshly killed sheep. They were exposed to ultrasonic disintegration and a preparation of cell walls was made by differential centrifugation.

2. The amino acid composition of acid hydrolysates of whole cells and cell walls was determined. Summation of these results shows that whole cells contained approximately $40 \%$ amino acids and cell walls approximately $30 \%$.

3. A considerable proportion of the alanine content of cell walls was present as the D-isomer, partly ester linked as in teichoic acids and partly more tightly bound in 'peptide linkage' being released only after hydrolysis in constant boiling hydrochloric acid.

4. Cell walls were found to possess an alanine racemase which was inactivated only after incubation of the cell walls in $0.1 \mathrm{M}-\mathrm{NaOH}$.

5. Whole cells contained approximately $8 \%$ carbohydrates and cell walls approximately $5 \%$. The glucose and galactose contents of whole cells and cell walls were low, accounting for little more than $2 \%$ of the dry weight of the bacterial samples.

6. The amino sugar content of bacterial samples was approximately $3 \%$ and consisted mainly of glucosamine.

7. The total lipid content of rumen bacteria was approximately $25 \%$ and that of cell walls varied considerably between 10 and $23 \%$.
\end{abstract}

There is evidence that microbial protein forms a large proportion of the total protein passing from the rumen (McDonald \& Hall, 1957; Weller, Gray \& Pilgrim, 1958). A number of experiments carried out to determine the nutritional value of rumen bacteria (Johnson, Hamilton, Robinson \& Garey, 1944; Reed, Moir \& Underwood, I949; McNaught, Smith, Henry \& Kon, 1950) have shown that they are as good a source of protein for rats as casein or gelatin. It is apparent therefore that rumen bacteria are of potential importance in the nutrition of sheep.

Of the components of the bacterial cell, the cell wall is of special significance as it often constitutes a substantial part of the total dry weight. For Escherichia coli the cell wall accounts for $15 \%$ of the dry weight (Salton, I964a). As the bulk of the bacteria found in the rumen are Gram-negative, cell walls from rumen bacteria may be expected to account for a similar proportion of the dry weight. As cell walls contain carbohydrate they may be of special significance as a source of glucose for ruminants. Of interest is the occurrence of D-amino acids in the bacterial cell wall and the presence of D-amino acid oxidase in sheep kidney and liver (Krebs, I935).

To provide knowledge about their potential nutritional significance to sheep, the present paper describes the preparation of rumen bacteria and cell walls of rumen bacteria and gives their detailed analyses. 


\section{EXPERIMENTAL}

\section{Removal of bacteria from rumen of sheep}

Rumen contents were collected from freshly slaughtered sheep that had been fed on grass. After filtering the contents through muslin, the coarse residue was resuspended in water, mixed by vigorous stirring with a vibrating stirrer and again passed through muslin. After two such treatments few additional bacteria were released from the sediment. The bacteria in the filtrate thus represented those bacteria which were not firmly associated with the sediment.

The filtrates and washings were centrifuged in a Sharples continuous flow centrifuge at $45000 \mathrm{rev} / \mathrm{min}$, using a flow rate of $20 \mathrm{ml} / \mathrm{min}$. The bacterial paste was resuspended in water and centrifuged at $100 \mathrm{~g}$ for $10 \mathrm{~min}$ in a Servall $\mathrm{SS}_{3}$ centrifuge at $4^{\circ}$ to deposit plant material and protozoa. The supernatant liquid was then centrifuged at $5000 \mathrm{~g}$ for $30 \mathrm{~min}$ to sediment all the bacteria. Examination of the supernatant fluid in the electron microscope showed that it contained very few whole cells and that these were all less than I $\mu \mathrm{m}$ in diameter. The pellet of bacteria was washed three times with a $0.9 \%(\mathrm{w} / \mathrm{v}) \mathrm{NaCl}$ solution and once with water. Part of this washed material was freeze-dried and part was used for the preparation of cell walls.

\section{Preparation of cell walls}

Washed bacterial suspensions consisting of I part wet weight and 4 parts water were subjected to ultrasonication in a $20 \mathrm{kc} / \mathrm{sec}$ sonicator (MSE Ultrasonic Disintegrator). Optimum breakage of cells was achieved with four periods of $90 \mathrm{sec}$ each, with $30 \mathrm{sec}$ for cooling between each treatment. Electron microscopy showed that very few cells were unbroken and that the cell walls were not unduly fragmented.

The method used for isolation of cell walls was based on that described by Salton \& Horne ( $195 \mathrm{I}$ ). Unbroken large bacteria were removed by centrifugation at $2000 \mathrm{~g}$ for $15 \mathrm{~min}$. The pellet consisting of unbroken cells and clumped cell walls was re-suspended in $0.9 \%(\mathrm{w} / \mathrm{v}) \mathrm{NaCl}$ and stirred with a vibrating stirrer. The suspension was centrifuged at $2000 \mathrm{~g}$ and the combined supernatant liquids containing the cell walls were then centrifuged at $20000 \mathrm{~g}$ for $30 \mathrm{~min}$ to sediment cell wall material. The pellet was washed three times in $0.9 \%(\mathrm{w} / \mathrm{v}) \mathrm{NaCl}$ and stirred with a vibrating stirrer. The suspension was centrifuged at $2000 \mathrm{~g}$ and the combined supernatant liquids containing the cell walls were then centrifuged at $20000 \mathrm{~g}$ for $30 \mathrm{~min}$ to sediment cell wall material. The pellet was washed three times in $0.9 \%(\mathrm{w} / \mathrm{v}) \mathrm{NaCl}$ and once in water. The cell-wall preparation was finally centrifuged at $2000 \mathrm{~g}$ for $15 \mathrm{~min}$ to remove any whole cells remaining and the supernatant liquid containing the cell walls was freeze-dried. The yield from roo $\mathrm{g}$ of bacteria was approximately $\mathrm{I} 5 \mathrm{~g}$ cell walls.

\section{Chemical analysis}

Amino acid analysis. Samples were hydrolysed, with constant boiling $\mathrm{HCl}$, after prior evacuation of air, for $22 \mathrm{~h}$ at $\mathrm{I} 10^{\circ}$. Hydrolysates were evaporated to dryness in vacuo over solid $\mathrm{NaOH}$ at room temperature. Amino acid analyses were done on a Beckman Amino Acid Analyser (Model 120B) by the standard technique of Moore \& 
Stein (1963) after passing samples through a millipore filter. Cystine and tryptophan were not determined.

Determination of D-amino acids. Cell-wall preparations were hydrolysed with constant boiling $\mathrm{HCl}$ at $\mathrm{I} 10^{\circ}$ for 24,48 and $72 \mathrm{~h}$ as above. D-Amino acids were assayed manometrically with pig kidney D-amino acid oxidase (Mann Research Laboratory Inc., New York).

Ester-linked amino acids were hydrolysed with $0 \cdot \mathrm{I} \mathrm{M}-\mathrm{NaOH}$ at $40^{\circ}$ for $30 \mathrm{~min}$, after which the cell walls were centrifuged at $10000 \mathrm{~g}$ for $30 \mathrm{~min}$ and the supernatant fluid was assayed manometrically for D-amino acids. As the cell-wall preparations contained an alanine racemase, the destruction of this enzyme by the alkali was always confirmed by adding L-alanine to a separate incubation system.

Racemase activity of cell walls. Alanine racemase activity of the cell walls was measured by following the conversion, with time, of L-alanine into D-alanine and vice versa. Cell walls were pre-incubated at $\mathrm{pH} 8.5$ in pyrophosphate buffer $(0.05 \mathrm{M})$ for $\mathrm{I} h$ at $38^{\circ}$ to remove D-alanine ester-linked to cell walls. Cell walls were incubated at $38^{\circ}$ in phosphate buffer $(25 \mathrm{mg}$ cell walls in $1.0 \mathrm{ml}, 0.05 \mathrm{M}$-phosphate buffer, $\mathrm{pH} 8.0$ ) with various concentrations of L- and D-alanine. Samples were then centrifuged at $20000 \mathrm{~g}$ for $20 \mathrm{~min}$ and the clear supernatant fluid was assayed for $\mathrm{D}$-alanine by a modification of the amperometric technique of Dixon \& Kleppe (1965). Pig kidney D-amino acid oxidase used in this assay was partially purified as described by Massey, Palmer \& Bennett (196r); the final purification by column chromatography was omitted.

Determination of sugars. Bacterial samples were hydrolysed in $\mathrm{I} M-\mathrm{H}_{2} \mathrm{SO}_{4}$ at $\mathrm{I}_{1} 0^{\circ}$ for $2 \mathrm{~h}$. Hydrolysates were neutralized with saturated $\mathrm{Ba}(\mathrm{OH})_{2}$ to $\mathrm{pH}_{4} \cdot 5$ and the $\mathrm{BaSO}_{4}$ formed was removed by centrifugation and washed twice with distilled water. The combined washings and hydrolysates were evaporated to dryness in a rotary evaporator at $30^{\circ}$. Sugars so obtained were chromatographed for $48 \mathrm{~h}$ on paper (Whatman No. 3) using butan-I-ol-ethanol-water (IO: I:2; v/v/v). Alkaline silver nitrate was used to develop colour (Trevelyan, Procter \& Harrison, 1950) as it enables detection of non-reducing sugars such as ribitol. Hydrolysates containing sugars were also gas-chromatographed as the acetyl derivatives by the method of Albersheim, Nevins, English \& Karr (1967).

The total carbohydrate content of bacterial samples was determined by the method of Dubois, Gilles, Hamilton, Rebers \& Smith (195I). Owing to interference by reducing substances released on the hydrolysis of bacterial cell walls, reductimetric methods are not reliable (Salton \& Pavlik, 1960) and for confirmatory reasons a number of different methods for estimating reducing sugars was therefore used. Hydrolysates were assayed for sugars by the method described by Somogyi (1945) and Nelson (1944) and by a modification of the neocuproine method (Brown, 1961) as described by Dygert, Li, Florida \& Thoma (1965). Cell-wall hydrolysates were also assayed by the anthrone method as described by Roe (I955).

Glucose and galactose determinations. Analysis of glucose using glucose oxidase was carried out by a method described by Dr B. J. Catley (private communication); it is based on the procedures described by Huggett \& Nixon (1957), Dahlqvist (1961) and 
Washko \& Rice (I96r). Galactose was determined using galactose oxidase as described by Roth, Segal \& Bertoli ( 1965 ) but lactoperoxidase was substituted for horse-radish peroxidase.

Amino sugar determination. Bacterial samples were hydrolysed in constant boiling $\mathrm{HCl}$ at $105^{\circ}$ for $2 \mathrm{~h}$, and hydrolysates evaporated to dryness in vacuo over $\mathrm{NaOH}$ at room temperature. After removal of humin, amino sugars were determined by the method described by Rondle \& Morgan (1955).

Total lipid determinations. An approximate value of the lipid content of cell walls was obtained by a modification of a method described by Wheeldon \& Collins (I957). Samples were extracted three times with $2:$ I $(\mathrm{v} / \mathrm{v})$ chloroform-ethanol. The combined filtrate was evaporated to dryness at $50^{\circ}$ on a water-pump. As this residue contains lipid associated with protein and polysaccharide, chloroform was added to dissolve lipid only. The filtrate was evaporated to dryness and weighed.

Table I. Amino acid composition of rumen bacteria and cell walls from rumen bacteria

(The results presented represent the average of four separate preparations of cell walls and two separate preparations of whole bacteria. The figures given in parentheses represent the range of values obtained. The moles $\%$ are presented exclusive of $\mathrm{NH}_{3}$ )

Amino acid

\begin{tabular}{|c|c|}
\hline Rume & acteria \\
\hline $\begin{array}{c}\% \text { of total } \\
\text { moles }\end{array}$ & $\begin{array}{c}\text { mg amino } \\
\text { acid residue/ } \\
\text { Ioo mg sample }\end{array}$ \\
\hline
\end{tabular}

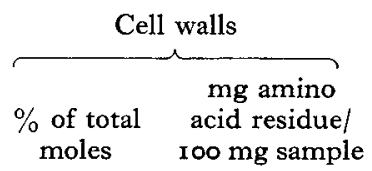

Crystalline bovine serum albumin

(for reference)

Lysine

Histidine

Arginine

Aspartic acid

Threonine

Serine

Glutamic acid

Proline

Glycine

Alanine

Valine

Methionine

Diaminopimelic acid

Isoleucine

Leucine

Tyrosine

Phenylalanine

$6 \cdot 5(6 \cdot 6-6 \cdot 3)$

$\begin{array}{ll}1.5(I .6-I \cdot 4) & 0.7(0.8-0.6) \\ 3.3(3.4-3.2) & I .9(I .9-I \cdot 8)\end{array}$

II.2 (I I.5-10.9) $4 \cdot 6(4 \cdot 6-4 \cdot 5)$

$6 \cdot 2(6 \cdot 2-6 \cdot 1) \quad 2 \cdot 3(2 \cdot 4-2 \cdot 1)$

$5 \cdot 7(6 \cdot 0-5 \cdot 4) \quad \mathrm{I} \cdot 8(2 \cdot 0-\mathrm{I} \cdot 6)$

I I.O (I I.3-10.7) $4.8(5.0-4 \cdot 6)$

$4 \cdot 1\left(4^{\cdot 2-4} \cdot 0\right) \quad \mathrm{I} \cdot 4(\mathrm{I} \cdot 5-\mathrm{I} \cdot 3)$

$9 \cdot 6(9.6-9.5) \quad 1 \cdot 9(2 \cdot 0-1 \cdot 8)$

I0.8 (I I.0-10.6) 2.9 (2.9-2.9)

$6 \cdot 3(6 \cdot 5-6 \cdot 0) \quad 2 \cdot 3(2 \cdot 3-2 \cdot 2)$

$\begin{array}{cc}2 \cdot 5(2 \cdot 5-2 \cdot 4) & I \cdot 3(1 \cdot 3-I \cdot 3) \\ \text { Trace } & \text { Trace }\end{array}$

$6.6(7 \cdot 2-5 \cdot 4) \quad 2 \cdot I(3 \cdot 1-1 \cdot 8)$

$\mathrm{I} \cdot 8(2 \cdot 6-\mathrm{I} \cdot 5) \quad 0.6(\mathrm{r} \cdot 0-0.4)$

$3 \cdot 4(3 \cdot 4-3 \cdot 3) \quad r \cdot 4(1 \cdot 8-1 \cdot 1)$

$10 \cdot 3(10 \cdot 8-9 \cdot 2) 3.0(4 \cdot 2-2 \cdot 5)$

$5.6(6 \cdot I-5 \cdot 2) \quad I \cdot 9(2 \cdot I-I \cdot 2)$

$5 \cdot 6(5 \cdot 7-5 \cdot 4) \quad 1 \cdot 3(x \cdot 7-1 \cdot 0)$

$10.4($ II.3-9.7) $3.5(4 \cdot 1-2 \cdot 6)$

$5.7(7.7-4.0) \quad 1.6(2.3-0.9)$

9.I $(9 \cdot 6-8 \cdot 6) \quad I \cdot 5(I \cdot 9-I \cdot I)$

I0. I (10.7-9.3) $2 \cdot 0(2 \cdot 6-1 \cdot 6)$

$6 \cdot 5(6 \cdot 8-6 \cdot 2) \quad I \cdot 7(2 \cdot 1-x \cdot 3)$

$I \cdot 7(2 \cdot 2-1 \cdot 5) \quad 0.7(1 \cdot 0-0.6)$

$0.6(1 \cdot 1-0.4) \quad 0.3(0.4-0.3)$

$\overbrace{\begin{array}{c}\text { mg amino } \\ \text { acid } \\ \text { total } \\ \text { moles }\end{array}}^{\begin{array}{c}\text { residue/ } \\ \text { roo mg } \\ \text { sample }\end{array}}$

Total amino acid

residue/100 $\mathrm{mg}$

$5 \cdot 4(5 \cdot 4-5 \cdot 3)$

$2 \cdot 2(2 \cdot 2-2 \cdot 1)$

$5 \cdot 3(5 \cdot 4-4 \cdot 3) \quad I \cdot 6(I \cdot 8-I \cdot 3)$

$7 \cdot 7(7 \cdot 7-7 \cdot 7)$

$3 \cdot 2(3 \cdot 3-3 \cdot 0)$

$8 \cdot 3(8 \cdot 5-8 \cdot 0) \quad 2 \cdot 4(3 \cdot 2-1 \cdot 9)$

$10 \cdot 4$
$2 \cdot 6$

$\mathrm{I} 2 \cdot 8$

$3.5(3 \cdot 6-3 \cdot 4)$

$2 \cdot 0(2 \cdot 2-\mathrm{I} \cdot 8)$

$3.2(3.8-2 \cdot 4) \quad$ I. $8(2 \cdot 1-I \cdot 2)$

$4 \cdot 5(4 \cdot 9-4 \cdot 1)$

$2 \cdot 4(2 \cdot 7-2 \cdot 0)$

$4 \cdot 9(5 \cdot 9-4 \cdot 4) \quad I \cdot 8(2 \cdot 3-I \cdot 3)$

$3 \cdot 4$

$9 \cdot 2$

6.3

$4 \cdot 2$

I $3 \cdot 5$

$5 \cdot 5$

$2 \cdot 5$

$7 \cdot 5$

5.5

0.4

$4 \cdot 0$

$5 \cdot 9$

10.9

$5 \cdot 8$

$4 \cdot 2$

$16 \cdot 5$

4.7

$\mathrm{I} \cdot 8$

$6 \cdot 2$

$5 \cdot 9$

0.8

100

$38 \cdot 2(40 \cdot 0-36 \cdot 4)$

I 00

$29 \cdot 2(36 \cdot 4-22 \cdot 2)$

$2 \cdot 0$

10.5

$3 \cdot 2$

$4 \cdot 2$

$2 \cdot 6$

$2 \cdot 2$

$5 \cdot 0$

$6 \cdot 5$

96 


\section{RESULTS \\ Amino acid composition}

Table I gives the amino acid composition of the rumen bacteria and of the cell walls. The results are presented as the averages of two separate preparations of bacteria and four separate preparations of cell walls. As a check on the analytical system, the amino acid composition of serum albumin is given.

\section{D-Amino acid content}

The 'total', and ester-linked, D-amino acid content of the cell walls is given in Table 2. For comparison the results obtained for a typical Gram-positive organism, Bacillus subtilis, and a Gram-negative organism, E. coli, are given. The results ob-

\section{Table 2. D-Amino acid content of cell walls}

(Mean values ( $\mu$ moles/100 mg dry weight) for three preparations of cell walls from rumen bacteria and two preparations of cell walls from $B$. subtilis and $E$. coli; ranges in parentheses)

\section{Sample}

Rumen bacteria cell walls

$B$. subtilis cell walls

E. coli cell walls
Total

$$
\begin{gathered}
4.4(3 \cdot 9-5 \cdot 8) \\
21 \cdot 5(20 \cdot 7-22 \cdot 3) \\
4.9(4 \cdot 5-5 \cdot 3)
\end{gathered}
$$

Ester-linked

$3 \cdot 7(2 \cdot 2-4 \cdot 8)$

$8 \cdot 3(7 \cdot 5-9 \cdot 0)$

$\mathrm{I} \cdot 3(0 \cdot 8-1 \cdot 7)$

tained suggest that the bulk rumen organisms are similar to $E$. coli but contain more ester-linked D-alanine. The D-amino acid content would probably represent D-alanine as the D-amino acid oxidase used does not have activity with D-glutamic acid, Daspartic acid and glycine. An increase in yield of D-amino acids in the hydrolysates with an increase in time of hydrolysis was observed, suggesting that the hydrolytic procedure caused racemization of $L$-amino acids. The extent of racemization $(3-5 \%)$ was of the same order as that measured by Ikawa \& Snell (1956) when casein was hydrolysed in the presence of starch. Extrapolation back to zero time was used to estimate the D-amino acids present.

\section{Alanine racemase activity of cell walls}

Fig. I shows a time-progress curve of racemization when both L- and D-alanine were the initial substrate. Increasing the concentration of $\mathrm{L}$-alanine in the incubation mixture increased the rate of racemization and the system was not found to be saturated up to $40 \mathrm{mM}$-L-alanine (Fig. 2). A plot of $\mathrm{I} / v$ against $\mathrm{I} / S$ gave a $K_{m}$ value of $10^{-2} \mathrm{M}$, where $v$ was the initial rate of reaction and $S$ was the initial substrate concentration.

\section{Carbohydrate content}

Table 3 gives the carbohydrate content of the bacteria and the bacterial cell walls. There was general agreement between the various methods. The carbohydrate content of whole bacteria was higher than that of cell walls, although the difference was not great (Table 3). Paper chromatography of cell-wall hydrolysates showed that at least seven sugars were present. They were an amino sugar, galactose, glucose, arabinose 
or mannose or both, ribitol, fucose and rhamnose. Gas-chromatographic analysis showed that both arabinose and mannose were present. Whole cells contained the same sugars as found in cell walls, with the addition of a considerable quantity of glycerol.

The glucose, galactose and amino sugar contents of the bacterial samples are given in Table 4. Analysis of hydrolysates in the amino acid analyser indicated that the major amino sugar present was glucosamine, with some muramic acid and galactosamine.

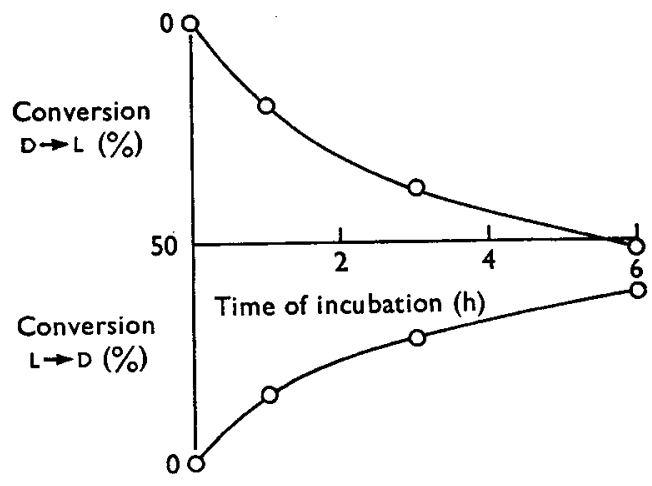

Fig. I

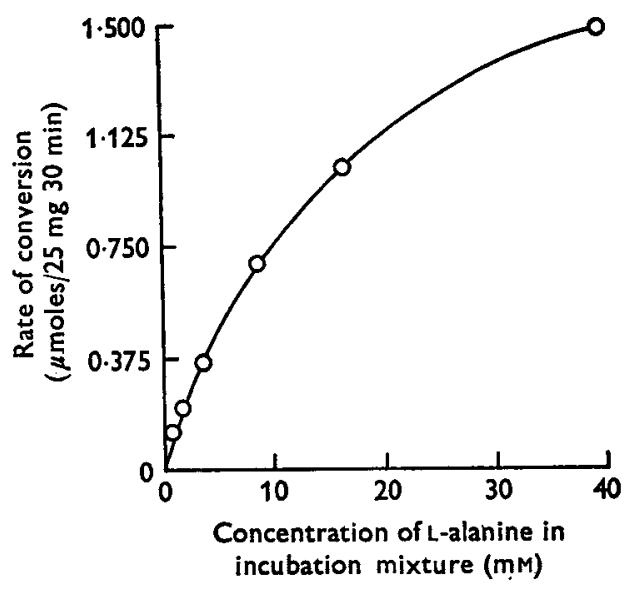

Fig. 2

Fig. I. Alanine racemase activity of cell walls from rumen bacteria. The cell walls were incubated in $2 \mathrm{mM} \mathrm{D}$ - and L-alanine for 1,3 and $6 \mathrm{~h}$ at $38^{\circ}$ and the D-alanine formed was measured amperometrically.

Fig. 2. The rate of conversion of L-alanine into D-alanine after incubation of cell walls in $O, I$, 4 , ro, 20 and $50 \mathrm{mM} \mathrm{L-alanine}$ at $38^{\circ}$ graphed against the corrected concentration of L-alanine in the incubation mixture.

\section{Table 3. Carbohydrate content of rumen bacteria and cell walls}

(Mean values ( $\mathrm{mg}$ glucose equivalents/100 $\mathrm{mg}$ dry weight) for four preparations of cell walls and two preparations of whole cells; ranges in parentheses)

\begin{tabular}{lcccc} 
& \multicolumn{4}{c}{ Method of analysis } \\
Preparation & Phenol/ $\mathrm{H}_{2} \mathrm{SO}_{4}$ & Somogyi/Nelson & Anthrone & Neocuproine \\
Cell walls & $4 \cdot 9(3 \cdot 8-5 \cdot 8)$ & $4 \cdot 5(3 \cdot 6-5 \cdot 1)$ & $4 \cdot 4(3 \cdot 5-5 \cdot 2)$ & $5 \cdot 1(4 \cdot 2-5 \cdot 9)$ \\
Whole cells & $8 \cdot 2(7 \cdot 9-8 \cdot 4)$ & - & $6 \cdot 8(6 \cdot 4-7 \cdot 2)$
\end{tabular}

Table 4. Glucose, galactose and amino sugar content of rumen bacteria and cell walls

(Mean values (mg/roo mg dry weight) for four preparations of cell walls and two preparations of whole cells; ranges in parentheses)

Preparation

Cell walls

Whole cells
Glucose

$0.4(0.3-0.5)$

$0.7(0.6-0.7)$
Galactose

$0.8(0.8-0.9)$

$\mathrm{I} \cdot 2(\mathrm{I} \cdot \mathrm{I}-\mathrm{I} \cdot 3)$
Amino sugar

$2 \cdot 1(1 \cdot 7-2 \cdot 6)$

$2 \cdot 8(2 \cdot 5-3 \cdot 0)$ 


\section{Lipid content}

The lipid content of four separate preparations of cell walls varied from to to $25 \%$ of the dry weight. The average lipid content of whole bacteria was higher, being $26 \%$.

\section{DISCUSSION}

The amino acid compositions of rumen bacteria isolated from sheep on widely different diets (Weller, 1957) have been shown to be closely similar. Apart from several strains where lysine, aspartic acid and glutamic acid vary, the amino acid composition of most strains of rumen bacteria obtained by Purser \& Buechler (1966) is similar to the amino acid composition of the bulk preparation of rumen bacteria obtained in the present study. Of the amino acids not synthesized in the tissues of the ruminant (Black, Kleiber \& Smith, 1952) only histidine is present in rumen bacteria in an amount less than 2 moles \%.

Although a number of amino acids other than D-alanine are present in bacterial cell walls as the D-isomer (Ikawa \& Snell, 1956; Toennies, Bakay \& Shockman, 1959), of those commonly present only D-alanine is determined with D-amino acid oxidase. It was found that up to $20 \%$ of the total alanine in cell walls from rumen bacteria is present as the D-isomer and that approximately half of this was ester-linked as in teichoic acids (Armstrong, Baddiley \& Buchanan, 1960).

It is reasonable to suppose that the bacterial racemase will still possess activity which persists for a time in the alimentary tract. The D-alanine arising in this way and directly from cell-wall hydrolysis may, after absorption, be the natural substrate for $\mathrm{D}$-amino acid oxidase in sheep liver and kidney.

The total carbohydrate content of rumen bacteria and cell walls (less than $10 \%$ of the dry weight) is considerably lower than that measured by McNaught et al. (1950) and Smith \& Baker (1944). The low glucose content as determined with glucose oxidase shows that the bacteria used in the present studies were almost entirely devoid of storage glucans. In this connexion, Heald (195I) found that following a sharp rise after a meal there was a rapid fall in glucan content. All the major sugars reported to be present in bacterial cell walls have been found present in the cell walls prepared from rumen bacteria.

Electron microscopic examination shows that many of the bacteria found in the rumen have capsules and flagella. It is likely that, to some extent, these are removed in the procedure for preparing cell walls; electron micrographs of the preparations do not show their presence. These capsular substances consist of polysaccharides and would therefore make a contribution over and above that estimated for the isolated cell wall.

A major difficulty in analysing the chemical composition of bacterial samples, particularly cell walls, is the complex associations existing between different cell components. Conditions required to hydrolyse one component often result in the destruction of other components. For example, increasing the time of hydrolysis of cell walls in $\mathrm{I} \mathrm{M}-\mathrm{H}_{2} \mathrm{SO}_{4}$ from 2 to $3 \mathrm{~h}$ was found to decrease the reducing sugar content of 
hydrolysates. The value for reducing sugar presented here is therefore unlikely to include the amino sugars from the cell-wall peptidoglycan as their release requires a more severe hydrolytic procedure than that used to release other reducing sugars (Salton, $1964 b$ ). Similarly, it was found that there was extensive humin formation on hydrolysing bacterial samples for amino acid analysis. The amino acid and carbohydrate contents of the samples therefore are unavoidably an underestimate of the actual amount present.

The possible contribution of the various bacterial components to the glucose requirements of sheep can be estimated on the basis of the results obtained. If approximately $260 \mathrm{~g}$ of bacteria pass out of the rumen per day (Hoogenraad, Hird, White \& Leng, 1970) then D-alanine present in the cell wall is likely to contribute no more than $0.2 \mathrm{~g}$ glucose. As determined by the methods used, the carbohydrates of the bacterial cell, if they are all glucogenic, could supply up to $20 \mathrm{~g}$ glucose. However, a number of sugars present such as rhamnose and glucose are not glucogenic in slices of rat kidney cortex (Krebs \& Lund, 1966) and the contribution of bacterial carbohydrates to glucose may therefore be less than $20 \mathrm{~g}$ per day. On the other hand, this estimation does not allow for the destruction of carbohydrate by the hydrolytic procedures used and the selective loss of capsular material during the preparation of cell walls.

As $260 \mathrm{~g}$ bacteria contain $100 \mathrm{~g}$ protein, gluconeogenesis from this source could supply $50-60 \mathrm{~g}$ glucose. This would represent a major contribution to the glucose requirements of sheep. Thus it was found in experiments with ${ }^{14} \mathrm{C}$-labelled bacteria (Hoogenraad et al. 1970) that preparations low in carbohydrate but high in protein were incorporated into glucose when injected into the alimentary tract of a sheep fed a roughage diet.

It can further be assumed that, on the basis of their similar chemical composition, bacterial cell walls from rumen bacteria are of similar potential nutritional value as whole rumen bacteria.

We acknowledge financial support from the Reserve Bank Rural Credits Development Fund and the Australian Research Grants Committee.

\section{REFERENCES}

Albersheim, P., Nevins, D. J., English, P. D. \& Karr, A. (1967). Carbohydrate Res. 5, 340. Armstrong, J. J., Baddiley, J. \& Buchanan, J. G. (I960). Biochem. F. 76, 610.

Black, A. L., Kleiber, M. \& Smith, A. H. (1952). Y. biol. Chem. 197, 365 .

Brown, M. E. (196r). Diabetes ro, 60.

Dahlqvist, A. (196I). Biochem. F. 80, 547.

Dixon, M. \& Kleppe, K. (I965). Biochim. biophys. Acta 96, 357.

Dubois, M., Gilles, K., Hamilton, J. K., Rebers, P. A. \& Smith, F. (1951). Nature, Lond. $168,167$.

Dygert, S., Li, L. H., Florida, D. \& Thoma, J. A. (1965). Analyt. Biochem. 13, 367.

Heald, P. J. (195 I). Br. F. Nutr. 5, 84 .

Hoogenraad, N. J., Hird, F. J. R., White, R. G. \& Leng, R. A. (1970). Br. F. Nutr. 24, 29.

Huggett, A. St. G. \& Nixon, D. A. (1957). Lancet ii, 368 .

Ikawa, M. \& Snell, E. E. (1956). Biochim. biophys. Acta 19, 576.

Johnson, B. C., Hamilton, T. S., Robinson, W. B. \& Garey, J. C. (I944). F. Anim. Sci. 3, 287.

Krebs, H. A. (1935). Biochem. F. 29, 1620.

Krebs, H. A. \& Lund, P. (1 966). Biochem. F. 98, 210.

McDonald, I. W. \& Hall, R. J. (1957). Biochem. F. 67, 400. 
McNaught, M. L., Smith, J. A. B., Henry, K. M. \& Kon, S. K. (r950). Biochem. f. 46, 32.

Massey, V., Palmer, G. \& Bennett, R. (196I). Biochim. biophys. Acta 48, r.

Moore, S. \& Stein, W. H. (1963). In Methods in Enzymology. Vol. 6, p. 819. [S. P. Colowick and N. O. Kaplan, editors.] New York: Academic Press Inc.

Nelson, N. (1944). J. biol. Chem. 153, 375 .

Purser, D. B. \& Buechler, S. M. (1966). ₹. Dairy Sci. 49, 8I.

Reed, F. M., Moir, R. J. \& Underwood, E. J. (1949). Aust. F. scient. Res. B 2, 304.

Roe, J. H. (1955). F. biol. Chem. 212, 335.

Rondle, C. J. M. \& Morgan, W. T. J. (1955). Biochem. F. 6r, 586.

Roth, H., Segal, S. \& Bertoli, D. (1965). Analyt. Biochem. 10, 32.

Salton, M. R. J. (1964a). The Bacterial Cell Wall, p. 246. Amsterdam: Elsevier Publ. Co.

Salton, M. R. J. (1964b). The Bacterial Cell Wall, p. 265. Amsterdam: Elsevier Publ. Co.

Salton, M. R. J. \& Horne, R. W. (195 I). Biochim. biophys. Acta 7, 777.

Salton, M. R. J. \& Pavlik, J. G. (I960). Biochim. biophys. Acta 39, 398.

Smith, J. A. B. \& Baker, F. (1944). Biochem. F. 38, 496.

Somogyi, M. (1945). F. biol. Chem. 160, 61.

Toennies, G., Bakay, B. \& Shockman, G. D. (1959). F. biol. Chem. 234, 3269.

Trevelyan, W. E., Procter, D. P. \& Harrison, J. S. (1950). Nature, Lond. r66, 444.

Washko, M. E. \& Rice, E. W. (196r). Clin. Chem. 7, 542.

Weller, R. A. (1 957). Aust. F. biol. Sci. ro, 384 .

Weller, R. A., Gray, F. V. \& Pilgrim, A. F. (1958). Br. F. Nutr. 12, 42 I.

Wheeldon, L. W. \& Collins, F. D. (I957). Biochem. F. 66, 435. 